\title{
I.JO'ГE
}

African Journal of Teacher Education
ISSN 1916-7822. A Journal of Spread Corporation

Vol.7 No. $3 \quad 2018 \quad$ Pages 1-21

\section{Sustainability of School-based Food Aid in Bahi District of Tanzania's Dodoma Region after the end of World Food Programme Support}

\author{
Joyce Nemes \\ Senior Lecturer \\ The University of Dodoma, Tanzania
}

\begin{abstract}
This study investigated the sustainability of school-based food drive after the phasing out of the World Food Programme (WFP) aid initiative in Bahi district of Dodoma region, Tanzania. The study found that none of the 72 public primary schools in Bahi district had managed to provide school lunch during the post-WFP period by October 2017. Only 10 schools managed to provide porridge rather than full lunch to the pupils during the review period. The public primary schools under review were unable to sustain the School Food Programme due to poor level of parental contributions, drought and widespread poverty. The study also found that parents complained about the school food programme lacking support within the national policy framework. The study recommends the application of the Resource Dependency Theory to sustain the SFP and government's intervention to boost agricultural production and empower the people to support their wards and the SFP at their wards' school.
\end{abstract}

Key Word: World Food Programme, School Food Programme, Sustainability, Mechanisms and Primary School.

\section{Introduction}

In Africa, many programmes and projects are financed through partnership between the government and donors. However, foreign aid has done little in the recent decade to change the conditions of many African states, most of which currently experience low growth rates (Andrews, 2009). Foreign aid is arguably important; however, it is not necessarily a panacea to African economic development (Aknor, 2007). Indeed, a better solution is suggested in the adage, 'do not give a fish to people but teach them 
how to get fish' so as to stimulate trade and development and reduce over-dependence on foreign aid (Rena, 2013).

The School Feeding Programme (SFP) is one of the initiatives financed as a partnership between the World Food Programme (WFP) and the Tanzania government. Launched in 2000, this project was implemented only on mainland Tanzania in the regions of Shinyanga, Dodoma, Arusha, Singida and Manyara. At the regional level, the SFP in Tanzania covered only some of the districts considered prone to hunger occasioned by the long dry seasons. Farmers in those districts suffer poor harvests as a result of a combination of factors such as the long dry seasons, poor agricultural technology and poor application of modern agricultural methods (URT, 2011 cited in Oganga, 2013: 15). According to Oganga (2013), fifteen districts and 1,116 schools and 572, 881 students were covered by the SFP in Tanzania in both the Northern and Central zones as indicated in Table1:

Table 1: Number of Schools and Students Covered by SFP in Northern and Central Zones of Tanzania

\begin{tabular}{|c|c|c|c|c|c|}
\hline \multirow[t]{2}{*}{ Zone } & \multirow[t]{2}{*}{$\begin{array}{l}\text { District under } \\
\text { the Programme }\end{array}$} & \multirow{2}{*}{$\begin{array}{ll}\text { Number of } \\
\text { schools }\end{array}$} & \multicolumn{2}{|c|}{$\begin{array}{l}\text { No of students } \\
\text { receiving food aid }\end{array}$} & \\
\hline & & & Male & Female & \\
\hline \multirow[t]{6}{*}{ Northern Zone } & Longido & 32 & 9,930 & 7,991 & \\
\hline & Monduli & 54 & 15,091 & 14,004 & \\
\hline & Karatu & 96 & 23,196 & 23,241 & \\
\hline & Simanjiro & 71 & 17,284 & 14,584 & \\
\hline & Ngorongoro & 60 & 17,051 & 12,884 & \\
\hline & Total & 313 & 8255 & 72,704 & 155,256 \\
\hline \multicolumn{6}{|l|}{ Central Zone } \\
\hline & Bahi & 70 & 18,722 & 18,844 & \\
\hline & Kiteto & 84 & 18,226 & 17,851 & \\
\hline
\end{tabular}




\begin{tabular}{|l|l|l|l|l|l|}
\hline & Chamwino & 110 & 24,605 & 25,883 & \\
\hline & Kondoa & 107 & 26,796 & 26,788 & \\
\hline & Iramba & 107 & 24,457 & 24,016 & \\
\hline & Mpwapwa & 115 & 26,709 & 28,518 & \\
\hline & Manyoni & 96 & 27,989 & 27,593 & \\
\hline & Kishapu & 20 & 4,484 & 4,598 & \\
\hline & Meatu & 20 & 6,487 & 6,561 & \\
\hline & Shinyanga rural & 20 & 4,598 & 5,00 & \\
\hline & Singida Rural & 104 & 23,708 & 25,162 & \\
\hline & Total & & 206,781 & 210,844 & 417,625 \\
\hline & 15 & 1,116 & & & 572,881 \\
\hline
\end{tabular}

Source: Prime Minister's Office, Dodoma, Cited in Oganga (2013: 16)

Table 1 indicates that the central zone had a lion's share of the number of schools that benefited from the WFP support compared to the Northern Zone. The persistence of drought in the Central Zone accounts for the preferential treatment accorded the zone.

The advantages of providing school lunch to pupils include improving the health, enrolment, attendance, retention, and performance of school-age children in addition to increasing community participation, especially when programmes depend on the community to prepare and serve meals in schools (WFP, 2012; Olubayo, Aluvi, \& Namusonge, 20013; Khatete, Pendo, \& Oyabi, 2013; Badri, 2014; Dey, 2014; Melaku, 2015; Sagenge, 2015; Yunisa, Gumel, Adegbus, \& Adegbus, 2015; Holo, 2015).

In Tanzania, the goals for improving nutrition were included in the Food and Nutrition Policy of 1992. It was also included in the national development plans and strategies, notably in the National Strategy for Growth and Reduction of Poverty, commonly known by its Kiswahili acronym of Mkukuta (Leach \& Kilama, 2009; URT, 1992). The government is also committed to the Millennium Development Goals (MDGs) number one, aimed to eradicate extreme poverty and hunger (Zaipuna, Yonah \& Cons, 2005; AFRODAD, 2005., UNECA \& AfDB, 2011) as well as the Sustainable 
Development Goals (SDGs) number one, which targets eliminating poverty for all in the country (Magoti, 2016; Twaweza \& SID, 2016). According to the National Vision of 2025, Tanzania projects a high quality of life for her population by 2025 (Magoti, 2016 \& Mallya, 2000).

Despite these commitments, the WFP phased out its SFP operation in 2015. This was anticipated given its scheduled implementation timeframe and attempts were made under the project to put in place various mechanisms to ensure its sustainability after WFP's withdrawal. The current Tanzania initiative of providing free primary education runs into the problems as government is unable to meet the costs of providing food for the children at school. Many poor families have come to believe that free public education should also come with free food.

A study conducted in Bahi by Rulenguka (2011) appraised the sustainability of the food for education programme in the district among primary schools. It established that the sustainability of the 'Food for Education' initiative was not guaranteed as community members in the in the project area were not fully involved in the planning and implementation of the programme.

There are contradictory views in the literature on offering children breakfast either at home or at school. On the one hand, the literature indicates that many children do not take breakfast at home before going to school due to shortage of food at home (URT, 1992; Kalinjuma, Mfuru, Nyoni, \& Modaha, 2013; Otieno, 2014; Taylor \& Ogbogu, 2016). On the other hand, the children with food in their homes fail to take breakfast due to lack of time before rushing to school or they simply lacked appetite in the morning (Melaku, 2015; Kalinjuma, Mfuru, Nyoni, \& Modaha, 2013). Besides, most pupils were not in schools that had special lunch arrangements (URT, 1992). In consequence, there was evidence of a hungry child that does not grow, that cannot learn properly and that faces many future health risks (Giliard, 2017). Studies show that poor school achievement, repetition of grades, and dropping out of school may result from poor nutrition status (Leach \& Kilama, 2009 \& Otieno, 2014). It is against this background that this study investigated the sustainability of the SFP in the post-WFP support period.

\section{Objectives of the Study}

This study aimed to collect pupils' and school management team's views on the sustainability of SFP in Bahi District in the post-WFP support phase. It sought to:

i. Examine the implementation of the School Food Programme in Bahi during WFP support. 
ii. Assess the mechanisms put in place to ensure the sustainability of school food programme in the post-WFP support period.

iii. Determine the factors that hindered public primary schools from implementing the mechanisms put in place to provide school food in the post-WFP support period.

\section{Theoretical Framework}

This study was guided by the Resource Dependency Theory (RDT) developed by Jeffrey Pfeffer and Gerald Salancik in 1978. The theory is premised on the prospects of communities' dependence on the environment for their survival (Pfeffer \& Salancik, 2003). The RTD perspective holds that for organisations to survive they need to acquire and maintain resources through interacting with external actors (Johnson, 1995, Pfeffer \& Salancik, 2003 cited in Althoz, 2010: 40; Nienhuser, 2008; Gomes, 2007; Sozen \& Yeloglu, 2009; Delke, 2015). The theory identifies financial and physical resources as well as information obtained from the environment as types of resources that organisations derive from the external environment for survival (Shehada, 2010). Under this theory, the interdependence between organisations and external actors are minimal.in environments where resources are abundant. Conversely, in environments where resources are scarce, organisations tend to face challenges due to their strong dependence on external actors (Gawish, 2016). However, this theory cautions that overdependency creates uncertainty which leaves an organisation vulnerable to external control. Generally, the RTD has three core ideas: (i) social context matters; (2) organisations' strategies for enhancing their autonomy and pursuit of their interests; and (3) power, which is important in understanding the internal and external actions of organisations (Davis \& Cobb, 2010).

A number of studies that have applied the RDT include by Werner (2008) who used the RDT to explain the behaviour of organizations; Delke (2015) who assessed and evaluated the contribution of the RDT to supply management in practice; and Peters (2014) who combined the RDT and the transaction cost theory to explain the Enterprise Rent a Car Company acquiring the Vanguard's National and Alamo brands in United State (US).

My region of study, Dodoma, Tanzania, is mostly semi-arid land with little annual rainfall and great susceptibility to drought and food shortage. A study recently conducted in Bahi district revealed that only 20.8 percent of the households sampled could afford the normal three meals a day. The study also confirmed that transitory household food insecurity is real in Bahi district (Myeya \& Kamangu, 2016). The study suggested that there was a large number of pupils who are affected by food insecurity 
in the area, a situation that can severely undermine their learning as hungry pupils can suffer from lack of concentration. Creating conducive environment for pupils to learn including the provision of school food in school, especially in drought-prone and poverty stricken areas such as Bahi was critical. This would ensure better health, better cognitive development, and higher concentration in class.

The study by Myeya and Kamangu (2016) implies that public primary schools in Bahi were not working in isolation from the external environments. In congruence with the RDT, they depend on the external environments for the sustainability of SFP, especially once the WFP support to the programme had run its course. Indeed, schools have to depend on educational stakeholders such as parents and donors to acquire resources, both financial and physical resources, including firewood, maize, sugar, and water. However, dependency on external support for SFP to survive creates some uncertainty.

\section{Methodology}

\section{Sample Size and Sampling Technique}

The study employed three sampling techniques: Purposive, stratified purposive and simple random sampling. Stratified purposive sampling was used to select eight Public Primary Schools (PPSs) whereas simple random sampling was used to select 109 standard six pupils. This was done after obtaining a list of standard six pupils from class teachers who have been in the same school since the pupils enrolled in standard one. The target was to select 120 pupils in the study from all public primary schools visited. Only 109 (90.8\%) pupils were eventually involved in the study because when the researcher visited two of the nine public primary schools under review barely a dozen pupils were present instead of 15 pupils expected. The target was to involve 120 pupils in the study from the public schools visited. Unfortunately, only 109 (90.8\%) pupils were subsequently involved in the study primarily because two of the public primary schools under review visited had less than 15 pupils in attendance. All pupils available meeting the set criteria were co-opted for participation in the study. Purposive sampling was also used to select one District Education Officer (DEO), one District Education Statistic and Logistic Officer (DELO), one Acting District School Health Co-ordinator (ADSHC), six Head Teachers (HTs) two Acting Head Teachers (AHTs), five School Committee Chairpersons (SCCs). These respondents were selected purposively because they had relevant information pertaining to the study. In all, 125 respondents were involved in the study.

Of the eight PPSs involved in the study three (37.5\%) only provided porridge, that is without lunch despite the pupils staying in school beyond lunch hours whereas five (62.5\%) PPS did not provide 
any food after the phasing out of the WFP support. Of those five PPSs which did not provide food, one (20\%) school was at an advanced stage of mobilising local resources to continue with the 'Food for Education' drive. The selection of these eight PPSs was based on the information obtained from the District Education Statistics and Logistic Officer who acted as the District Education Officer during the first day of the visit. The target was to include at least five schools which managed to provide food after the phasing out of WFP support to SFP. But none of the schools in Bahi had managed to do so sustainably by October 2017. According to the District Education Statistics and Logistic Officer, of the 72 primary schools in Bahi, the number of schools that managed to provide only porridge did not exceed 10. These few schools included Uhelela, Ngombolala, Mnkola, Mundemu and Lamaiti. During fieldwork only three of those schools mentioned were providing porridge. In other words, the study included only three primary schools that provide porridge.

\section{Methods of Data Collection}

Interviews, Focus Group Discussions (FGDs), document review and observation were employed to collect data. Interviews were held with the District Education Officer, head teachers, school committee chairpersons and school health teachers who were key informants. Semi-structured interviews enabled the researcher to get in-depth information from the respondents pertaining to the study (McNamara, 1999). All the respondents were interviewed in their offices for about 45 minutes each. Focus group discussions, on the other hand, were held with standard six pupils. During the study, the researcher also reviewed official documents such as school committees' minutes on the SFP and the records of parental contributions towards the food drive. Moreover, the researcher carried out observations of the kitchen, utensils, availability of water, general economic status, grains collected, pupils taking their share of porridge during break-time and students turning up after lunch hour in primary schools visited during the study.

Before field visits, ethical requirements such as getting permission from the University of Dodoma, the Regional Office and District Education Officers were adhered to. In addition, participation of all the respondents was voluntary and the researcher prepared a consent form and all the standard six pupils who participated in the study had their parents sign on their behalf.

\section{Data Analysis}

Overall, the process of qualitative data analysis in this study went through three stages of describing the phenomenon, classifying it and seeing how the concepts interconnected. Based on the emerging 
patterns and themes in line with the objectives of the study, the researcher was able to develop a comprehensive description of the subject of the study on the SFP in the post-WFP support period. Then, the researcher classified the data by interpreting and explaining in accordance with the research objectives as outline above. Finally, following data classification, the researcher established logical connections between the resultant categories (Dey, 2005).

\section{Presentation and Discussion of Findings}

\section{Public Primary Schools during the Implementation of WFP-Supported SFP}

Findings from interviews revealed that all the eight primary schools involved in the study were beneficiaries of the WFP-supported SFP. This programme started in earnest in 2010 before being phased out in 2015. Information obtained from FGD with 109 pupils revealed that SFP was implemented in their schools from the time they were in pre-primary level in 2011 to the time they had reached Standard four in 2015. Detailed information obtained from the DESLO during an interview also revealed that the WFP initially started implementing the SFP on pilot basis in eight PPSs of Chipanga ward in 2008 before scaling it up and by 2010 it was fully functional in all the 72 PPSs of Bahi district:

WFP started in 2008 in eight selected pilot primary schools of Chipanga ward. Some of primary schools which were in the piloted programme includes Chipanga A, Chipanga B, Chikola, Chilingula... Then the programme was scaled up and fully implemented in 2008 in all the 72 public primary school of Bahi District (Interview with Bahi DESLO 17/10/2017).

During the life-span of WFP-supported SFP all the eight (100\%) PPSs received foodstuffs like maize, rice, beans and peas as well as cooking oil. The amount of food disbursed was determined by the number of pupils registered in the respective schools. Schools also received token contributions from parents or guardians which ranged from TAS500-1000. The funds obtained was used for grinding grains, purchasing salt and soap for washing utensils, and partly for paying wages of cooks and security guard. Pupils were also each levied a 5-litre container filled with water every morning in addition to firewood whenever necessary.

It was also established that salary payment of security guards and cooks varied from one school to another. For security guard the salary ranged from TAS 25,000 to TAS 40,000 whereas for cooks it 
ranged from TAS 30,000 to TAS 50,000, all varying from school to school. Porridge was provided to the pupils during break time at $10.20 \mathrm{am}$. During the lunch hour from $12.20 \mathrm{pm}$, pupils ate ugali (maize flour meal) with peas or beans, rice with beans or peas and sometimes cooked blend of maize and beans commonly known in Kiswahili as "makande" depending on the school timetable. Thus as the study by Rulenguka (2011) established, porridge, ugali and beans were the foods mostly provided to primary school children during the WFP-supported SFP in Bahi district. However, makande with vegetables was a rare commodity on the menu as parental contributions to the WFP-supported SFP Rulenguka, (2011).:

Table 2: Parents' Contributions during the WFP-supported SFP in Bahi District

\begin{tabular}{|l|l|l|}
\hline $\begin{array}{l}\text { Name } \\
\text { School }\end{array}$ & Ward & Parents' Contributions and Utilisation during WFP \\
\hline Uhelela & Bahi & $\begin{array}{l}\text { Parents contributed TAS 500 per month. The sum obtained was used } \\
\text { for grinding grains, purchasing salt and salary payment. Security } \\
\text { guard was paid TAS 30,000 and two cooks employed were paid TAS } \\
30,000 \text { each per month. }\end{array}$ \\
\hline Bahi Misheni & Bahi & $\begin{array}{l}\text { Parents contributed TAS 500 per month. The sum obtained was used } \\
\text { for payment of salary for of three chefs @ TAS 50,000 each per } \\
\text { month. The amount was also used for grinding grains and purchasing } \\
\text { salts. }\end{array}$ \\
\hline Ngombolola & Ibihwa & $\begin{array}{l}\text { Parents contributed TAS 1,000 per month. The sum was used for } \\
\text { salary payment of two cooks @ TAS 50,000 each per month and of } \\
\text { a security guard @ 50,000 per month, and for the purchase of salts } \\
\text { and soap for washing utensils. }\end{array}$ \\
\hline Mnkola & Ibihwa & $\begin{array}{l}\text { Parents contributed TAS 5,000 per term, with the sum used for } \\
\text { payment of two cooks @ TAS 40,000 each and one security guard } \\
\text { and buying salt and soap. }\end{array}$ \\
\hline
\end{tabular}




\begin{tabular}{|l|l|l|}
\hline Sanduli & Bahi & $\begin{array}{l}\text { Parents contributed TAS 5,000 per term; used for salary payment of } \\
\text { a security guard @ TAS40,000 and two cooks @ TAS50,000 each } \\
\text { per month, and for grinding grains and purchasing salts. }\end{array}$ \\
\hline Bahi Sokoni & Bahi & $\begin{array}{l}\text { Parents contributed TAS1,000 per month. The sums obtained were } \\
\text { used for salary payment of two cooks @ TAS 40,000 each and one } \\
\text { security guard TAS 40,000. }\end{array}$ \\
\hline Mundeme & Mundeme & $\begin{array}{l}\text { Parents contributed TAS 500 for three mouths. That sum was used } \\
\text { for paying salary of two cooks @TAS 30,000 each, one security } \\
\text { guard TAS 30,000 per month, grinding grains and purchasing salt. }\end{array}$ \\
\hline Lamaiti & Lamaiti & $\begin{array}{l}\text { Parents contributed TAS 750 per term. That sum was used for the } \\
\text { payment of two cooks @ TAS 40,000 each and one security guard } \\
\text { TAS 30,000. }\end{array}$ \\
\hline
\end{tabular}

Source: Field Data (2017)

Data presented in Table 2 suggests that there were variations among the schools in terms of the amount of money parents or guardians contributed to the WFP school food initiative. There were also variation in the amount of salary paid to the cooks and security guards from one school to another. The funds collected from parents/guardians' was one of the determinants of how much the cooks and security guards would be paid under the SFP. As the head of one school explained:

Only few parents managed to contribute to the supporting costs during the WFP-funded SFP. The situation was so worse off that the teachers used their pocket money to grind the grains and purchase salt (Interview with the female acting head teacher 27/10/2017).

\section{Sustainability Mechanisms for the SFP in the Post-WFP Support Period}

Three types of plans that have been put in place to save pupils from hunger after the phasing out of WFP in Bahi district. First, the District Executive Director, together with the DEO, directed the heads of school to inform parents of their need to each contribute $10 \mathrm{kgs}$ of grains for lunch in schools per year. None of the eight primary schools had managed to provide school lunch, though six Head Teachers and two Acting Head Teachers of primary schools reported that they had implemented the directives from the District Education Officer office to hold meetings with parents in collaboration 
with Village Chairperson, Ward Education Co-ordinators and School Committee Members to sensitise and raise awareness on the importance of contributions to enable schools continue the SFP. The most some of the schools accomplished was to provide some porridge after the WFP support had been phased out; and only three (37.5\%) schools were able to provide porridge at 10.20 am based on parents/ guardians' contributions. One (12.5\%) of the remaining schools was finalising the resource mobilisation process, while four $(50 \%)$ primary schools with no contribution having come from parents or guardians failed to provide any food to the pupils.

Table 3: Current School Lunch Situation and Mechanisms put in Place to Ensure Sustainability of SFP

\begin{tabular}{|c|c|c|}
\hline $\begin{array}{l}\text { Name } \\
\text { School }\end{array}$ & $\begin{array}{l}\text { Current Situation Regarding } \\
\text { Provision of School Lunch After } \\
\text { Phase out of WFP }\end{array}$ & $\begin{array}{l}\text { Mechanisms Put in Place to Insure } \\
\text { Sustainability of WPP }\end{array}$ \\
\hline Uhelela & $\begin{array}{l}\text { Providing Porridge since August, } \\
2017\end{array}$ & $\begin{array}{l}\text { Parents contribute Sorghum } 1 \mathrm{~kg} \text { of grain } \\
\text { and TAS } 100 \text { per month. }\end{array}$ \\
\hline Bahi Misheni & Did not provide any food & $\begin{array}{l}\text { They planned to conduct parents' meeting } \\
\text { in December } 2017 \text { to inform them about } \\
\text { the matter for the second time. }\end{array}$ \\
\hline Sanduli & Did not provide any food & $\begin{array}{l}\text { They conducted one parents' meeting to } \\
\text { inform them about the matter; none of } \\
\text { parent/guardians' volunteered for } \\
\text { effecting the agreed upon contribution. }\end{array}$ \\
\hline Ngombolola & $\begin{array}{l}\text { Providing Porridge since } \\
\text { September } 2017\end{array}$ & $\begin{array}{l}\text { Each parent contributes } 5 \mathrm{kgs} \text { of sorghum } \\
\text { per term. }\end{array}$ \\
\hline Mnokola & $\begin{array}{l}\text { In advanced stage of mobilising } \\
\text { resources for SFP }\end{array}$ & $\begin{array}{l}\text { Managed to mobilise } 7 \text { bags of sorghum. } \\
\text { The agreement was for each parent to } \\
\text { contribute } 5 \mathrm{~kg} \text { of grains and } 1 / 2 \mathrm{~kg} \text { of sugar } \\
\text { per term. }\end{array}$ \\
\hline
\end{tabular}




\begin{tabular}{|c|c|c|}
\hline Sokoni & Not providing any kind of food & $\begin{array}{l}\text { They conducted three different parents' } \\
\text { meeting to inform them about the matter. } \\
\text { So far only one parent managed to } \\
\text { volunteer and the school management } \\
\text { decided to refund that parent's } \\
\text { contribution. } \\
\text { They planned to cultivate five hectares of } \\
\text { sorghum in the coming rain season } \\
\text { starting end of November } 2017 \text {. }\end{array}$ \\
\hline Mundemu & $\begin{array}{l}\text { Pupils coming from far distances } \\
(3 \mathrm{~km} \text { to } 5 \mathrm{~km}) \text { carrying food from } \\
\text { home and stored in a school store } \\
\text { for lunch }\end{array}$ & $\begin{array}{l}\text { The school planned to cultivate five } \\
\text { hectares of sorghum in the coming season } \\
\text { of rain which start end of November } 2017 \text {. }\end{array}$ \\
\hline Lamaiti & $\begin{array}{l}\text { Providing porridge since WFP } \\
\text { phase out up to June } 2016 \text {. They } \\
\text { planned by August } 2017 \text { to start } \\
\text { again to provide porridge }\end{array}$ & $\begin{array}{l}\text { Parents contributed } 4 \mathrm{~kg} \text { of sorghum per } \\
\text { month and TAS } 1500 \text { per term for grinding } \\
\text { grains and salary payment of one chef @ } \\
\text { TAS } 40,000 \text {. } \\
\text { The school planned to cultivate five } \\
\text { hectares of sorghum in the coming season } \\
\text { of rain which start end of November } 2017 \text {. }\end{array}$ \\
\hline
\end{tabular}

Source: Field Data (2017)

The second plan put in place was the directive from the District Education Officer requiring all the heads of schools in Bahi district to cultivate at least 5 hectares of sorghum in each school in the coming season of rain, which started at end of November 2017. According to the District Education Statistics and Logistic Officer, the directive arose after realising that most of the pupils in the schools under review went to school hungry because parents were unable to contribute grains for preparing even school porridge for their children. This five-acre sorghum plan was projected to capacitate these schools to provide some porridge and lunch to ease the burden of often reluctant parents to continue making contributions to the food upkeep of their children while in school. 
A third plan was at Mundemu Primary School, where the school committee had introduced a school by-law that allowed pupils who come to school from some distance, about $5 \mathrm{~km}$, to bring packed lunch from home. Usually, the lunch boxes are stored in a school store monitored by a school heath teacher and the teacher on duty to be collected at $12.20 \mathrm{pm}$ mid-afternoon lunch break. Yet, not all the pupils were able to bring packed lunches due to a severe shortage of food in their homesteads. During the study the researcher also observed packed food in a school storage. According to the acting female head teacher:

We have 15 pupils who come with packed lunch. They trek over $5 \mathrm{~km}$ from here. We put their food in our store. It is safe. During lunch hours they took their food and eat (Interview with the female head teacher 27/10/2017).

...pupils coming from Matitu Street which is located $5 \mathrm{~km}$ from our schools are allowed to bring packed lunch. Others fail to come with food because at home there is nothing. ... One day a pupil collapsed; I picked her up and drove her on my motorcycle back home. As we reached her home she said I need water and porridge. Thereafter she became normal (Interview with the School Committee Chairperson 27/10/2017).

This incident attests to how the provision of school food can save pupils coming from poor family backgrounds and those trekking over long distances from school premises. The school food programme can attract them to attend schools on regular basis and improve their concentration in the classroom and eventually can enhance their academic performance.

\section{Hindrances to the Primary Schools Sustaining SFP}

The study revealed that none of the schools had managed to continue providing school lunch after the WFP support had been phased out from the SFP. Second, Not all schools managed to provide porridge by July 2017 as directed by the DED via the District Education Office. Third, in the three primary schools that managed to provide porridge, not all the parents contributed grains and money as per agreement during the PTA meeting. Also, the rate of parents' contributions varied from one school to another. In other words, the mechanisms in place to collect contributions of grains and money from parents and guardians were largely ineffective. The following are the factors affecting sustainability school food provision in the post-WFP support phase: 
Slow parents' contributions of grains and money as were agreed upon during the ParentsTeachers Association (PTA) meetings: For instance, at Uhelela Primary School, which provided porridge, they had agreed during the parents-teachers meeting to start providing porridge by July 2017 but due to the slow pace of contributions from parents, this did not begin until August 2017. Of the school's 358 pupils, actual parents' contribution by August 2017 was only 100 (27.9\%), 128 (35. \%) by September 2017 and 148 (41.3\%) by October 2017. As a result, the school only allowed those pupils whose parents had made contribution to partake in the porridge. The result was that pupils who did not contribute but live near school premises decided to head back home for lunch whereas other pupils who came afar remained in the school compound without food. Those of the latter who had money bought snacks from the school compound or from near the school.

It remains to examine whether those pupils go home return to school in time for the resumption of classes and if they do, what the nature of their concentration was in the classroom during afternoon lessons, and whether the food they at ate home was nourishing enough. Gilliard (2017) found that the absence of a school food programme forced many village pupils to return home and cook for themselves as their parents were either working in the farms or in town centres trading. As a result, such pupils end up performing poorly because of tiredness or hunger (if they skipped the lunch) or worse still some develop unacceptable social behaviours such stealing money from their parents to buy snacks at school.

Lamaiti Primary School with 729 pupils which had targeted collecting 50 bags of sorghum and TAS 1,093,500 was only able to collect 33 bags (66\%) and raised only TAS 663,870 (60.7\%) cash. Parental contributions at Lamaiti Primary School were far more impressive than in other schools and all pupils in this school were allowed to share in the morning porridge. Moreover, the school arranged a follow-up process with the village government to ensure those who did not yet contribute do so as required by their agreement. At Mnokola, the school was in the process of mobilising resources. It had seven bags of sorghum saved in the school store. According to the head teacher, the school's enrolment was 559 pupils but only 91 pupils had managed to contribute $5 \mathrm{kgs}$ of sorghum, half $\mathrm{kg}$ of sugar and TAS 2,500 to buy sugar and pay for other operational services by $19^{\text {th }}$ October 2017. Despite such a slow pace of contributions, plans were underway to start providing porridge to the pupils. It was not clearly established whether all the pupils, including those who did not make the required contributions would be allowed to have the porridge when the school commences its provision. Other schools 
visited - Bahi Misheni, Bahi Sokoni, Sanduli and Mundemu—have set in place a plan similar to those of Lamaiti and Mnokola to sustain the SFP, but nothing had been collected by October 2017 when the researcher visited those schools.

These findings generally raised concern on the pace of parents' participation in making contributions for the first term which lasted up to December 2017 even though contribution started in July 2017 during the harvest season. The second academic term would start in January 2018 and end June 2018 when the next harvest would begin. There still seems to be little prospect for the successful take off of the SFP.

Head teachers interviewed indicated that officials at the district level have to visit their respective schools to assist them with sensitisation and awareness raising campaign of the parents on making contributions of resources for the school food initiative. The study findings contradict those obtained by Oganga (2013) in Chamwino district where parents were judged willing to contribute definite amount of food but not cash at the beginning of every school calendar.

Drought was another factor mentioned that hindered the primary schools visited from implementing the plans put in place. During the 2016 season, there was famine in the area due to drought, hence making it difficult for parents to contribute grains. This confirms declaration by the National Adaptation Programme of Action (NAPA, 2007: 38 cited in Njau, Farrelly and Masumbuko, 2014: 375) that Dodoma is one of three regions ranked top on the list of drought-stricken areas of the country. Other studies conducted in the study area show that more than 60 percent of the households experienced difficulties in feeding their members. The situation became aggravated in February when the percentage of distressed households increased to between 81.1 to $94.8 \%$ (Mayaya, Opata, Kipkorir, 2015). According to Matunga (2008) December to February are the months of food shortage in Dodoma. These months are also the pre-harvesting period and it is in that period that the majority of families have no stock of food in their granaries. Generally, the amount of food which was stored could not last until the following harvesting season. Under such circumstances, the findings of the current study indicate that there is an urgent need for public primary schools in the study area to get support from external environments to have impactful and sustainable SFP (Nienhuser, 2008; Shehada, 2010; Gawish, 2016).

Some parents argued that what was given to the pupils was too inadequate to banish their hunger. While the researcher observed pupils getting a share of half a litre of porridge at Ngombollola 
and Lamaiti primary schools, it served more as an excuse than a justification for parents' refusal to participate actively in the school food programme. Some parents who live close to the school insisted that they saw no need for such programme that made them incur additional costs unnecessarily.

Some Head teachers, Acting Head Teachers School Committee Chairpersons interviewed said that they faced difficulties in mobilising grains and money from parents due to the prevailing educationis-free mentality, which made some parents desist from making any contribution. This confirms that parents still depend on government hand-outs or donor support. These findings are in line with those in Chamwino district where some of the parents were reluctant to contribute money and they were demanding that those who constructed the school toilets were also responsible for providing funding for the water and hygiene facilities to maintain the toilets (Nemes, 2014). Some parents complained that the programme was not a countrywide food initiative, hence limiting its effectiveness by depending on parents and guardians' contributions.

Finally, the study found that the parents' income in the study area was too low to allow them to contribute grains and money to the school for SFP as required. Even at Mundeme, it was noted that parents were unable to prepare packed lunch for their children despite their homes being located more than $5 \mathrm{kms}$ away from the school. According to the Acting Head Teacher, some of the parents hardly had any food at home to allow their children to take some to school. These findings are also in line with those of Holo (2015) who found that of 60 percent of parents in Kiteto district were unable to contribute for their school meals simply because of poverty; they could not afford even to have three meals per day.

\section{Conclusion and Way Forward}

This study makes three observations on SFP in Bahi district of Dodoma region in the post-WFP support period. First, during the life-span of the WFP-supported SFP, parents and guardians were contributing money for the payment of cooks and security guards in addition to their children supplying to their school five litre containers of water every morning and some firewood where necessary. Second, after the 2015 phase out of WFP support in Bahi district, the DED office via the District Education Officer directed all Head Teachers to convince parents to contribute grains for the school food programme. However, none of the primary school managed to provide school lunch by October 2017, and the number of schools providing porridge did not exceed 10. Thirdly, the DED office via District Education Officer office have come up with another alternative of directing all Head Teachers in Bahi 
District to ensure that in the next season of rain which started in November 2017 they cultivate at least five hectares of sorghum to reduce the burden on parents and allow pupils to have porridge and lunch at school as required. However, public primary schools involved in this study are not self-sufficient to sustain SFP. Thus, as the dependency theory requires, these schools need support from parents and other educational stakeholders in terms of contributions to sustain the SFP, particularly in the postWFP support period. Their inability to meet targets demands that they look for alternative external support to sustain the SFP.

The study, therefore, recommends the government should devise strategies to boost agricultural production in the study area, including establishing irrigation schemes instead of leaving the task squarely in the hands of head teachers and village governments. In addition, community should use good land conserving agriculture methods, mixed cropping, gentle slope cultivation and drought resistant plants (Ephrahim \& Fadhili, 2014). Finally, parents and other education stakeholders should shoulder their responsibility of contributing to the wellbeing of their children at school and ensure they are fed rather than depend on the state for everything.

\section{References}

Abed, M. G. (2015). A consideration to two main ethical issues in educational research and how may these be addressed. Managers' Journal on Educational Psychology, 8(3), 1 -14.

African Forum and Network on Debt and Development (AFRODAD). (2015). "Tanzania and the millennium development goals: A Critical appraisal of the global partnership for development (Goal 8). Harare: Zimbabwe.

Altholz, V. (2010). The advantages and limitations of developing and external perspectives for analyzing cooperate strategic alignment. Economic and Environmental Studies, 1(1), 35 - 48.

Aknor, K. (2007). Foreign aid to Africa: A hollow hope. NYUJ Int'l. \& Pol, 40, 1071.

Andrews, N. (2009). Foreign aid and development in Africa: What the literature says and what the reality is. Journal of African Studies and Development, 11 (10), 008 -015.

Badri, A.Y. (2014). A review of the progress of school meal programs in the globe. Sky Journal of Food Science, 36, $052-060$. 
Dey, I. (2005). Qualitative data analysis: A user-friendly guide for social scientists. London and New York: Taylor \& Francis Group.

Davis, G. F. \& Cobb, J. A. (2009). Resource Dependency Theory: Past and Future.

Delke, V. F. (2015). The resource dependency theory: Assessment and evaluation as a contributing Theory for Supply Management. Bachelor's thesis, University of Twente.

Ephrahim, K.V. \& Fadhili, B. (2014). Climate change adaptation in semi-arid Dodoma: An experience from Eco - Village. Journal of Challenges, 2(2), 30 - 42.

Gawish, R. (2016). Studying the relationship between foreign donors and NGOs in developing countries: An effective or volatile partnership? A case study of human right -focused NGO behaviour in Egypt. Unpublished MA in Political Science Dissertation. Cairo: The American University in Cairo.

Gilliard ( $4^{\text {th }}$ April 2017). Tanzania: Why Mbeya struggles to attain education target. The Citizen. Available at http://allafrica.com/stories/201704050138.html.

Gomes, L.O. M, (2007). Proposing Theoretical Framework to investigate the Relationships between an Organization and its Environment. RAC, 11(1), 75 -95.

Holo, S. (2015). Impact of school feeding on student attendance in Secondary Schools: A Case of Kiteto District in Tanzania. Unpublished MA Education in Administration, Planning and Policy Studies. Dar es Salaam: The Open University of Tanzania.

Johnson, B.L., Jr. (1995). Resource dependency theory: A political economy model of organizations. University of Utah.

Kalinjuma, A.V., Mafuru, L., Nyoni, N \& Modaha, F. (2013). Household food and nutrition security baseline survey for Dodoma, Iringa, Njombe and Singida. Survey report. Food and Nutrition Centre and TAHEA Iringa. Pamaja Tuwalee MVC Project.

Khatete, I.W., Pendo, S. \& Oyabi, J. M. (2013). School Feeding Programme and pupils' participation in primary schools in Kenya: A Study of Taita Taveta and Nairobi District. Journal of Emerging Trends in Educational Research and Policy Studies (JETERAPS), 4 (6), 895 -900.

Leach, V. and Kilama, B. (2009). 'Institutional analysis of nutrition in Tanzania' Special Paper 09.31 Dar es Salaam. REPOA. 
Magoti, E. (2016). Did Tanzania achieve the Millennium Development Goal? Statistical Analysis. Journal of Education and Practice, 7(8), 58 -69.

Mallya, E.T. (2000). A critical look at Tanzania’s Development Vision 2025.

Matunga, B. N. (2008). Causes of food insecurity and coping strategies in Tanzania: A case of small holder farmers in Chamwino district. A dissertation in partial fulfilment of the requirements for the degree of masters of arts in rural development of Sokoine University of Agriculture, Morogoro, Tanzania.

Mayaya, H.K., Opata, G. \& Kipkoriri. E. C. (2015). Understanding climate change and manifestation of its driven impacts in the semi-arid area of Dodoma Region, Tanzania. Ethiopian Journal of Environmental Studies \& Management, 8(4), 364 -366.

McNamara, C. (1999). General guidelines for conducting interview. Minnesota.

Myeya, H. E \& Kamangu, A. (2016). Assessment on the state of household food security in Bahi District, Tanzania. International Journal of Food Nutrition and Safety, 7(3), 126 -137.

Melaku, T. (2015). School Feeding Program nutritional assessment study report. Light Ethiopia. Addis Ababa, Ethiopia.

Nemes, J. (2014). The Water and Sanitation (WASH) drive in Tanzania: Opportunities and challenges head teachers face in Rural - Based schools. International Journal of Education and Research, $2(1), 1-12$.

Nienhuser, W. (2008). Resource Dependency Theory: How well does it explain behaviour of organization. Management Review, 19(1+2), 9-32.

Njau, F. B., Farrelly, M. and Masumbuko, I. (2014). Climate vulnerability and capacity analysis in Dodoma Region of Tanzania. Research Desk, 3 (1), 374 - 391.

Oganga, B. N, (2013). Feeding students? Examining views of parents, students and teachers on the World Food Program's School Feeding initiatives in Chamwino District in Tanzania. Master's Capstone Projects. 28. http://scholarworks.umass.edu/cie_capstones/28.

Otieno, D. (2014). Influence of school feeding programme on academic performance of pre-school children in Kayole Zone, Nairobi County. A research submitted in partial fulfilment of the award 
of a bachelor degree in Early Childhood Education. Department of Education, Communication Teaching, University of Nairobi.

Olubayo, M. A., Aluvi, P. A. \& Namusonge, G. (2013). Factors affecting implementation of school feeding programme in public primary schools in Kenya: A survey of Emuhaya Sub-County, Kenya. International Journal of Science and Research (IJSR), 4I (8), 1431 - 1436.

Pfeffe, J. \& Salancik, G. R. (2003). The external control of organizations: A resource dependence perspective. Stanford University Press.

Peters, M. R. (2014). Resource dependency \& transaction costs: investigating recent mergers in the US rent-car industry. Journal of Management and Marketing Research, 15(1), 1- 6.

Rena, R. (2013). Is foreign aid panacea for African problems: The case of Namibia. Managing Global Transitions, 11(3), 223 -241.

Robins, S. P. \& Coulter, M. (2007). Management. New Delhi: Prentice - Hall of India.

Rulenguka, B. S. (2011). An appraisal of the sustainability of the Food for Education Programme in Bahi District primary schools, Dodoma Region. Unpublished M.A. (Education) Dissertation. Dar es Salaam: The University of Dar es Salaam.

Sagenge, A. J. (2015). Impacts of School Feeding Programme on access in primary school education in Chamwino District, Tanzania. Unpublished MA Education in Administration, Planning and Policy Studies. Dar es Salaam: The Open University of Tanzania.

Shehada, F. (2010). Strategic organizational responses to environmental pressures: The case of Three Palestinian Non - Governmental Organizations. A Dissertation Submitted to the Graduate School - New York, the State University of New- Jersey.

Sozen. C. \& Yeloglu, H.O. (2009). Interorganizational and Interdepartmental Resource Dependency of E-Government Applications. International Journal of eBusiness and eGovernment Studies, 1 (1), $15-26$.

Tanzania Food and Nutrition Centre (2014). Tanzania National Nutrition Survey 2014, Final report data collection: 24 September - 21. Dar es Salam: November 2014. Dar es Salaam: Ministry of Health and Social Welfare. 
Taylor, A. D. and Ogbogu, C.O. (2016). The effects of School Feeding Programme in enrolment and performance of public elementary school pupils in Osun State, Nigeria. World Journal of Education, 6 (3), 39 - 47.

The United Republic of Tanzania (URT) (1992). The food and nutrition policy for Tanzania. Dar es Salaam: Ministry of Health.

UNECA, U. \& AfDB, A.U. (2011). Assessing progress in Africa toward the Millennium Development Goals. MDGS Report.

United Nations. (2015). The Millennium Development Goals report 2015.

Werner, N. (2008). Resource dependency theory, how well does it explain behaviour of organizations. Management Review, 19(10), 9-32.

World Food Programme (WFP) (2012). School meals opening doors to education in Tanzania.

Yunusa, I., Gumel, A. M. Adegbusi, K \& Adegbusi, S. (2012). School feeding programme in Nigeria: A vehicle for nourishment of pupils. The Symposium: An Online Journal of the African Educational Research Network, 12 (2), 104 -110.

Zaipuna, O. \& Yonah. R. (2005). ICT as too for poverty reduction. Proceeding of the discourse on engineering contribution in poverty reduction March $18^{\text {th }}-19^{\text {th. }}$ In AED 2018 pp. 41-61. 